\title{
Myths of Violence
}

\author{
Brad Evans \\ University of Bath; B.Evans@bath.ac.uk
}

\begin{abstract}
This essay critically addresses ten prevailing assumptions about violence: (1) violence is natural; (2) violence comes easily to humans; (3) violence attacks a juridical life; (4) violence is the result of underdevelopment; (5) violence is the result of difference; (6) violence is a sign of absolute power; (7) violence is associated with some death drive; (8) violence can be intelligent through a mastery of technology; (9) the opposite of violence is a just peace; and (10) violence is an assault on the sacred meaning of life. In doing so, it opens up a conversation on the meaning of political violence and makes an impassioned call to free ourselves from sacred myths that bind us to a problem that still appears insurmountable.
\end{abstract}

Keywords: violence, power, development, difference, myth, the sacred

\section{Introduction}

How we understand violence is key to how we conceptualise every single political category. We know nothing of claims to democracy, security, rights, justice and human development without attending to its underwriting demands. But what if the ways this understanding was framed rested upon highly contestable assumptions and political claims? We know violence is a complex phenomenon that continues to defy neat description. And we know it is poorly understood if reduced to actual bodily assault. Violence is an attack upon a person's dignity, sense of selfhood and right to participate in this world. Moreover, violence is absolutely integral to the markings of subjectivity, setting apart claims about identity, along with notions of civility and barbarism. Violence is always mediated through expressed dichotomies between acceptable and unacceptable behaviours, between the right to punish and the intolerable transgression, between the force of normative law and the terror of the minority. In fact, there is an entire political ecology at work in the very diagnosis of something as political violence in itself.

What can also be said is the problem of violence still seems insurmountable to us today. It always appears before us as timeless and timely - historically set and fully in keeping with the contemporary (dis)order of things. Our best chance of survival then, it seems, is to learn to civilise violence and push it to the margins of society. And yet this too demands a certain mask of mastery, for the claims to have better perfected its appearance has relied fully on the stripping away of any diagnosis of deeply structured forms of everyday violence whose effects are often hidden in plain sight. Hence, to break the cycle of violence means we have to develop a critique of violence that is adequate to our times and learn to undo the mythical binds that continue to force us to see violence as something which is inevitable, unavoidable and an integral part of the human condition. The purpose of this essay is to offer a number of provocations that challenge ten commonly held ideas about violence - ideas upon which contemporary logics of power and political rule continue to depend. In doing so, it presents a case for rethinking the political.

\section{Violence is Natural}

The opening sequence to Stanley Kubrick's 2001: A Space Odyssey remains the best representation of the prevailing assumption concerning human evolution and development. In the beginning, it is said, man was nothing more than a beast, once solitary then tribal, living on survival instinct alone. As we evolve, so we learn to master technologies that demonstrate our computational skills, along with our abilities to massacre one another with more ruthless efficiency. Man, in fact appears as a killer ape 'with metaphysical longing', as Simon Critchley observes ${ }^{1}$. We reason ourselves beyond the insecure sediment of existence, trying to find meaning for a life Thomas Hobbes famously explained to be 'nasty, brutish and short' if left to its own devices. The very idea of the security imperative so foundational to modern politics

62

Journal of Humanitarian Affairs Volume 2, No. 1 (2020), 62-68 @ The authors http://dx.doi.org/10.7227/JHA.035

This is an Open Access article published under the conditions of the Creative Commons Attribution-NonCommercial-NoDerivatives licence https://creativecommons.org/licences/by-nc-nd/4.0

MANCHESTER 1824

Manchester University Press 
has been premised upon such a belief and the notion that there is such a thing as a violent instinct that is revealed in a natural state of life. Over time, naturalist assumptions have become integral to racial essentialisations and violence inflicted on lesser 'savage peoples'. The very idea of colonialism would be premised on the ability to mark out as racially inferior entire continents of people, who could be rightfully condemned, as indigeneity meant they were one step closer to the barbarism of nonmetropolitan life. But even as the most enlightened liberal replaced crude biological determinants with its equally prejudicial cultural markers, so the idea that humans were still naturally violent remained the normalised truth regarding the history of the human condition and its political maturity. Hence, what remained was to question how we regulated this violence; which system of government, in other words, would save us from ourselves.

Nature is nothing more than an imperial construct ${ }^{2}$. Writ large over colonisation and the modern will to rule, it provided the sure moral and civilisational basis for taming 'savage life's. While claims of native violence were mythologised and consecrated through Orientalist frames throughout the period of colonial imperialism (Said, 2019), the very idea that nature entailed violence and civilisation entailed its ending has never stood up to empirical fact or any serious philosophical scrutiny. In fact, the more philosophers have applied the gardening metaphor to tame the wilderness and its state of political animality (Bauman, 1991), the more they have reduced humans to the level of wild beasts and have authored genocides in its name. And yet the ontological idea that life needs to be made partially secure by drawing upon a sovereign claim to order remains a constant in all dominant forms of political reasoning. Just walk into any natural history museum and look upon the version of the past presented with sure scientific veracity. From the opening exhibits featuring some prehistoric hominids crouched in some dark and dank cave, to men walking on the moon shadowed by clouds of a nuclear Holocaust, so our entire history is commonly narrated as a tale of survival against the odds. That the history of the human condition is a natural history of violence is rarely questioned today. And yet, in times of extreme collapse, humans often show their very humanness, compassion and dignity, and it is often those indigenous peoples most attuned with nature who have contributed the least to ecological degradation who should be most deserving of our respect and attention.

\section{Violence Comes Easily to Humans}

A picture of impending dystopian realism is part of the contemporary reckoning ${ }^{4}$. Collapse, anarchy, violence - the surest signs the explosive potential was always there. We might make a crude point here and say that if our basic level instinct is survivalist, and this in turn has shaped the prevailing account of politics as a means to protect life from its unmediated desires, then every human has a violent impulse deeply woven into consciousness and memory. That we are not violent owes everything to the ways in which violence has been removed from us through our cultured and civilised models for human understanding; it has in effect been unlearned as a direct result of our pedagogical influences and the evolving disciplinary mechanisms of the state. But we only need to be put into a slightly different environment, advocates say, whether its Stanford or Abu Ghraib, for us to reveal our truer selves and show how seemingly good people can commit evil acts (Zimbardo, 2008). Violence in this regard can be seen as a liberating expression of base human instincts.

Followers of René Girard might attribute sacred meaning to life in order to set the limits of violence through the very appearance of the sacrificial taboo (see below). Others may point to the force of law and how it acts as a meaningful deterrent to the unmediated life, which can all too easily reveal its inner demon and violent urges. Not only has this idea been used to domesticate the potentially resistive masses, endorsing a certain type of punishment; it also overstates the outrage to structural forms of violence. If humans truly were naturally violent and that violence came easily to them, would there not be more cases of violent outrage and self-destruction among impoverished communities? What is more, most of the extreme cases of human slaughter throughout history have taken place within the bounds of domestic and international law. They have been fully in keeping with the prevailing normative claims to truth and its ritualised performances. Very rarely does violence come to us in a truly sporadic or spontaneous way. All political violence has a history and most often it is carried out with cold, reasoned calculation. What is more, such violence demands considerable organisation and psychological investment in order for it to be effective. Therefore, the association of violence with an always-already irrationality is misleading.

\section{Violence Attacks a Juridical Life}

Violence is a process. It has a history. It has a past, and it has a future. It shapes memory and acts as the most formidable pedagogical force, instructing us about what to love and what to hate, what to fear and what to trust, what to uphold and what to allow to perish for the good of community and humanity complete. Violence is also highly mediated between its legitimate versus illegitimate expressions. Central to these processes are concerns with 
dehumanisation and the denial of rights. To repeat: violence is an assault upon a person's dignity. It is 'an ontological crime' (Cavarero, 2007), which not only injures or punishes, but also forces life to behave in entirely different ways. Importantly, since modern life is constituted and given its very sense of meaning through legal power and the rights bestowed through institutional arrangements (national and international), what passes for illegitimate violence is seen as a direct assault on the right to life as juridically framed. If law protects, the transgression of such declarations brings the rights of the subject into question. All other concerns in the enactment of violence follow on from this initial break in the sovereign trust. There would be no political violation were the laws respected - at least, this is what the notion of a juridical life implies.

Law can always be put to the service of violence. The outcome of historical battles, its pronouncements are never objective, self-evident or universally applied (Evans, 2013). Arendt's claim that violence can be justified but never legitimate must be reversed: violence is often legitimated in political arenas and juridical courts; but it can never be justified through an invocation of justice, except where the latter is limited to a reductive juridical paradigm. Justice is not law (Derrida, 1992). Justice is the ability to live a life with dignity and free from lawful violence. Justice in this regard is not the end of power. It is an ethical positioning that brings into question all forms of violence, most especially the legitimate violence constituted through the force of law. Denying the constituted embodiment of life, lawful violence is dehumanising. This in turn gives rise to claims about the universal rights of humans in international law and its associative laws of war.

\section{Violence is the Result of Underdevelopment}

Domesticated in the shadow of juridical power by the threat of incarceration, critics of the previous position might also point to our shared material gains and sense of prosperity ${ }^{5}$. The modern compulsion to rule over planetary life was made possible by directly appealing to the twinned imperatives of order and progress. This would be upheld by a formidable school of intellectual thought, where ontology was firmly securitised, and the idea of progress tied to the epistemic development of human discovery and technological advancement that emerged again from naturalist understandings of human savagery. While, as mentioned, the onset of racial violence predicated on claims to the innate backwardness of certain 'races of peoples' resulted in name of the 'enlightened spirit', it would also be reworked into more racially sensitive and objective ways ${ }^{6}$. As liberal replaced race with culture and class with entitlement, so the advent of a globally ambitious claim to govern all planetary life could overcome all claims to sovereign integrity by appealing directly to the notion that underdevelopment was dangerous. While violence was therefore complex, since complex systems were less about linear root causes and more about states of dynamic connection and interaction, earlier claims concerning the 'origin of the species' could be neatly set aside by a more objective narrative supported by empirical scientific truths.

To be underdeveloped is to be closer to the unmediated condition of human survival. And once thrown back into that regressive state, people return to their unlawful barbarism in order to survive. While the shift from race to culture allowed for more subtle and yet al. together more pervasive critiques of non-European subjects that could now take aim at entire life-world systems, the displacement of class with entitlement would permit the continuation of inequality, with blame apportioned to the poor for their own plight. Indeed, since the entitlement model (as a re-scripting of earlier enlightenment assumptions on the progressive contours of a meaningful life) sought an effective break with colonial history and its lasting effects among the world of peoples, so this bourgeois construct proved capable of moralising the power of political economy and putting development workers at the forefront of the fight to deal with unnecessary suffering in zones of abandonment and crises. Resistance aside for now, what's often left out of this narrative is precisely how the organisation of violence takes considered financial and material investment to ensure its sustainability over time. Indeed, the very idea of a liberal peace that emerged through this progressive account of human cohabitation proved to be a complete misnomer, as it wilfully and violently destroyed illiberal forms of planetary life.

\section{Violence is the Result of Difference}

The idea of racial violence is part of a broader schematic that connects to competing claims to historical truth. What is often seen to be at stake here, however, is not just the claim to victory in the battle over resources. It has everything to do with different worldviews concerning how life should be made to live. That difference is the principle cause of violence is the prevailing understanding at the heart of all modern theories of conflict ${ }^{7}$. Differences are seen to set us apart and when they come into tension, violence will necessarily erupt - especially when the scarcity of resources is factored into the equation. This has certainly been true for realists who 
see the world as an open conflict between different and competing nations (with the invariable threat of anarchism always lurking in the shadows), to modernists more generally who see the world as being threatened by the tensions caused between secularism and religious orthodoxy, and to those liberals who have appropriated Carl Schmitt's point about politics being all about friends versus enemies. Difference, then, is the problem to be solved or at least safely managed.

Violence results not from violence but from forced homogenisation and the colonisation of the Other. The greater the universal claim to truth, the greater the violence needed to bring about its realisation. It is no coincidence that two competing entities in any conflict often resemble one another. Whether we elect to call this mimesis or dialectics, in the order of battle, the two entities need each other to create a unifying reciprocity that legitimates both in the violent struggle over meaning and truth. Sceptics may invariably either point to the apparent successes of liberal universalism in creating for a moment in history a semblance of peace, or counter by well-rehearsed claims of cultural relativism. Like John Rawls before him, Steven Pinker has nothing meaningful to say about structural or racial violence. To accept difference is not to accept the existence of ISIS or compromise with a paedophile. There is no ethics of difference from another who has no respect for difference $^{8}$. What we do know is that the ineradicability of difference is often invoked to destroy difference in the name of universality, to murder in the name of peace, to show utter disregard in the name of tolerance.

\section{Violence is a Sign of Absolute Power}

The idea that illegitimate violence is an expression of absolute power is well established ${ }^{9}$. This is not a comment on the links between fascism and violence, which have been amply documented (though how we conceive of fascism needs to be severed from its ideological moorings). Let's return to the idea put forward by Hannah Arendt that violence is precisely the impotence of power (Arendt, 1970). Without the capacity to convince through non-coercive means, it is now called upon to punish the resistance such that the ends will always justify the means. But no relationship between living things can ever be sustained through violence alone. Or when it does, that is when the fatalistic end of fascism - its nihilism - is revealed, as it realises it cannot destroy all resistance without destroying itself. Nihilism is after all the will to nothing ${ }^{10}$. And it ends at nothing, for oppressor and oppressed alike. So, there is no power over life if such power is fully exhausted. The purpose of such violence then is to surgically intervene at various frequencies and intensities in order to normalise the power over life and live out the fascistic dream. That doesn't mean to say the threat of violence ever truly dissipates from the relationship. Once the power over life is normalised, the spectre of violence is in fact omnipresent. It has to be that way or else the still existent capacity to resist might result in a reversal of fortunes. In the absence of violence there is an absence of fear. And in the absence of fear life can live affirmatively, creatively, resistively in the primary and ontological sense of these terms, with all the public and joyful expressions of difference that freedom entails. But let's not forget that what is resistive can also become violent in response. This in turn creates a brutal dialectic, which appearing as war by everyday means, creates a unifying reciprocity where both parties end up fighting over the same object of desire - a violence based on similitude not differentiation. Hence, in revolution, everything changes so that everything remains the same.

Rather than seeing violence as the privilege of absolute power, it is better to see it as the outcome of asymmetric freedom. The freedom to punish or destroy, which triumphs over the freedom to resist or the freedom to flee. Paul Virilio was correct: all wars are wars of movement (Virilio and Lotringer, 1983). And as Gilles Deleuze further rightly insisted, if a person is so oppressed, it is not that their rights are being denied but rather that their movements are restricted (Deleuze, 1995: 122). Arendt showed that in cases of extreme violence, what marks out the distinction between perpetrators and victims was that everything was possible, and nothing could be resisted (Arendt, 1976). But no system of power is absolute. There is always the capacity for resistance. Indeed, what the history of fascism shows is that its claim to power is always deeply vulnerable and riven with deep anxieties. If we are to have any faith in the 'human spirit', surely it stems from the realisation that humans will resist the patently intolerable. They do not need to read Marx, Fanon, Arendt, Foucault to do so. Perhaps a better account of the history of the human condition, then, is not one that privileges the natural propensity for violence, but one that privileges the desire to live with freedom and harness the creative and resistive energies of life - which notably in conflict with others, affirms difference as a condition for non-violent political transformation. What is fascism, after all, if not, as Arendt maintained, a ghastly experiment to destroy 'spontaneity itself as an expression of the human condition?

\section{Violence is Associated with Some Death Drive}

Our violence (never referred to as 'violence', but designated using tolerable labels, such as 'force') is 
always presented as the last resort or completely necessary, their violence purely destructive. While we can agree with Nietzsche that nihilism is a motor of modern history, it is a mistake to see it in purely negative terms. One of the greatest myths about contemporary violence is still connected to rather old psycho-analytical insights concerning fatalism and the egotistical downfall of the deluded man. Freud's notion of the death drive in many ways is integral to the de-legitimation of the violence we do not like on account of its negation of human existence (Freud, 1991). Of course, it is necessary to understand the psychic life of violence, and to understand why the masses can elect oppression as though it were liberation. Violence can be seductive, and it can also be psychologically purifying, especially for those who have long been subjugated by it. But more often, those who justify violence do not put themselves on the side of death. However deluded and deceptive, only the most bizarre suicidal cults can be explained in the terms Freud explained.

From fascism to liberalism (the two never so distant), al-Qaeda to Assad, ISIS to Israel, what marks out claims to violence is precisely the idea that a better world awaits its realisation. Hence, despite the impotence of violence, that doesn't mean to say it cannot be put into service to reproduce or create entirely new regimes for political power and bio-political control. Violence is not simply negative. It conditions the possibility of political rule, setting out in the clearest ways the lines of belonging and expendability, the force that's always measured versus the plight of the damned. This is why violence can so easily be accommodated by the technocratic wisdom of a progressive mind. We are governed, as Foucault noted, by the power over life; bio-politics can disallow life to the point of death. Violence is progressive and progress is often extremely violent in its normalisation.

\section{Violence Can Be Intelligent through a Mastery of Technology}

If war has been the motor of history, technology has been the motor of war. But what makes technology so masterful is precisely the way it can be presented as ambivalent and its advancing technical armies as objective. Technology has distanced the perpetrator of violence from their victims. It has been well documented how during the Great Wars, for example, the majority of men refused to fire their weapons. A point developed by Lt. Col. Dave Grossman, who not only explains the need to be more selective in the production of trained killers but acknowledges that most will experience deep traumatic effects upon return (Grossman, 2009). But technology is not simply about overcoming the challenges of dehumanising the victim. Technological control is predicated upon the possibility of intelligent violence, which in the process of minimising casualties and speeding up the delivery of violence, actually appears humane. Technology then is not anti-human. It is the only thing that might save us. A point made by the scientist Richard Gatling, who, trying to justify his invention of the gun, noted: 'If war was made more terrible, it would have a tendency to keep peace among the nations of the earth.' The same redemptive narrative would be promulgated by those responsible for the atrocious nuclear assault on Japan, in 1945.

The tragedy, however, is that the more we seek to regulate or civilise violence by giving ourselves over to the technological account of human progress, the more we increase our chances for collective annihilation. Indeed, despite the potential human benefits of technological advancement, the triumph of the technical over the poetic in political affairs undermines the role of human creativity. How many critical theorists still have to affirm the importance of arts and humanities to the promotion of peace? Theory and science are not objective: we produce the technologies we desire, which are over-coded with all manner of assumptions and prejudices. So, as the technological mind continues to produce war machines in continual pursuit of advancement, from drone technologies to big data surveillance systems, what is ultimately being destroyed is the ability to imagine all too human relationships that put ethics before technological claims.

\section{The Opposite of Violence is a Just Peace}

Millions have been brutally slaughtered in justification of lasting peace. History shows that the most apparently peaceful regimes can in fact be the most tyrannical. We only need to think here about the brutal vision of peace and stability brought to Afghanistan in the early years of Taliban rule. Since all violence has a history, no claim to peace can be made in relation to a permanent state of affairs. What might be peaceful to some can be suffocating and oppressive to others. Peace in fact never appears before us like some self-evident revelation, except in the most theological pronouncements. We can think of the liberal peace here as the evident example. Claiming to rid the world of all unnecessary evils and political conflicts, advocates of the liberal peace openly waged war upon supposedly illiberal elements across the world, while confiscating any political claim to resistance from a different ideological persuasion. All the while, liberal peace operations often normalised vulnerability and insecurity in lands where peace once resided. And yet the ontologising of vulnerability came up against its own violent limits, drawing forth the pent-up rage and 
anger among downtrodden white populations in the liberal democratic West.

We could return here to the enduring appeal of Immanuel Kant, who was the first to propose the idea of a perpetual peace. Notwithstanding contentions regarding Kant's racism and lack of concern about the slave trade, Kantian philosophy and its juridical appeal truly offer a terrifying vision for humanity complete. Kant proposes a harmonious regulation of the faculties of reason. He imagines a world free from conflict, frictionless in its thoughts, autonomous in its rationality, committed in its pursuit of happiness. And yet not only does this require the eradication of all resistance, Kant, still needed to account for those who didn't wish to conform to his universal doctrine. It is therefore no coincidence that he ended his life writing about the concept of evil. Perpetual peace is a moral force, which reveals most fully why liberalism has always been a sociodicy. And yet, even Kant had to concede that this vision of peace, in the end, belonged in the graveyard. We do not lack ideas about peace in the world; what we lack are ideas concerning resistance to the present. A resistance to the image of a world that continues to annihilate us on a daily basis. Presenting the claim of peace as a terrifying adaptation of Hieronymus Bosch is a meaningful start.

\section{Violence is an Assault on the Sacred Meaning of Life}

The claim that violence results from a lack of respect for the sanctity of life is perhaps most indicative of a mythological history of violence. Girard was the most incisive thinker on this history, showing that all social orders are born of some original traumatic sacrificial act (Girard, 2005). But this sacrifice is nothing to be lamented. It becomes the regulatory taboo, which, giving sacred meaning to life, means that we have a much better grasp on its metaphysical purpose. The sacrificial act is loaded with moral and political symbolism, presenting before us what is right and what has been wronged, thereby allowing us to use its example to push violence to the margins of society. While we may never fully eliminate violence, we can then at least accommodate ourselves with its appearance, learn to mobilise its effects and draw upon its sacred wisdom from time to time. The sacrifice thus becomes the warning and something to behold as we continue to suffer into the truth of existence.

We can understand a great deal about history by asking what sacred objects appear and cut through the fabric of time. Our history in fact can be mapped out through the embodiments of the sacred, from the body of Christ and its sacred positioning within Christianity, to the body of the hero whose sacrifice was so integral to the modern nation-state, on to the victim, who became the sacred object for liberal rule. ${ }^{11}$ However, countering Girard's mythical assertion that the sacred allows us to domesticate violence by giving immense meaning to life, what we can alternatively say is there would be no possible way to justify any form of political violence without the sacred object and its worldly claims. Just as we know nothing of claims to democracy, security, rights, justice and human development without attending to violence, we know nothing about community, protection, dignity and love without sacrifice. This is the most entrenched and allegiant of all our claims to violence, which justifies killing for the love, protection and retribution of persons who we feel so ethically and personally connected to.

That violence persists in the world today is not merely coincidental to the persistence of myths about violence. The insistence that violence cannot be combatted or overcome, but only resisted and managed, contributes to the permanence of violence in multiple forms. A world free from violence in a way that still permits the affirmation of creative and resistive subjectivities is not beyond us. But the creation of this world requires a different concept of the political. A concept of the political that doesn't see difference as a problem to be solved, nor believe that violence is inevitable, and humans violently fated. A concept of the political, then, that gives over to a politics of love that breaks free from the binds that violence has placed around our wrists, demanding our sacrifices and reaffirming its necessity.

\section{Notes}

1 This point was made by Critchley in a filmed interview with the production Big Think discussing the Psychology of Murder. Online at: https:/www.youtube. com/watch?v=tJ7noA0zJwk (accessed 10 July 2019).

2 This idea is central to social Darwinism and the development of notions of 'nature' that can be scientifically explained and verified.

3 On this, see Foucault's work on the history of race and how it connects to notions of the savage and the barbarian; in particular, Foucault (2003). See also, Duffield (2005).

4 For more elaboration on the concept of 'dystopian realism' see Evans and Giroux (2015).

5 This reasoning is at the heart of the liberal peace thesis. It would also be extended onto reasons about the successes of liberalism in bringing about global peace and prosperity, notably with Pinker (2011).

6 The most incisive author on this has been Mark Duffield. See, in particular, Duffield (2001) and Duffield (2007). 
7 Whilst this understanding is most clearly expressed in the work of Samuel Huntington, it is also central to liberal notions of universality. For an excellent critique of the latter see Gray (2007).

8 I have explored this question of ontological difference (notably borrowed from the ideas of Gilles Deleuze) in relation to the Zapatistas of Mexico. See Evans (2008) and Evans (2010).

9 On this, see Forti (2014).

10 For an excellent mediation on the concept of nihilism see Brassier (2007).

11 Accounting for the changing nature of sacred violence is the focus of my forthcoming book (Evans, 2021).

\section{Bibliography}

Arendt, H. (1970), On Violence (New York: Harvest Books).

Arendt, H. (1976), The Origins of Totalitarianism (New York: Harcourt Brace).

Bauman, Z. (1991), Modernity and the Holocaust (Cambridge: Polity Press).

Brassier, R. (2007), Nibil Unbound: Enlightenment and Extinction (New York: Palgrave Macmillan).

Cavarero, A. (2007), Horrorism: Naming Contemporary Violence (New York: Columbia University Press).

Deleuze, G. (1995), Negotiations: 1972-1990 (New York: Columbia University Press).

Derrida, J. (1992), 'Force of Law: The "Mystical Foundation of Authority", in Cornell, D., Rosenfeld, M. and Carlson, D. G. (eds), Deconstruction and the Possibility of Justice (New York: Routledge).
Duffield, M. (2001), Global Governance and the New Wars: The Merging of Development and Security (London: Zed Books).

Duffield, M. (2005), 'Getting Savages to Fight Barbarians: Development, Security and the Colonial Present', Conflict, Security \& Development, 5:2, 141-59.

Duffield, M. (2007), Development, Security and Unending War: Governing the World of Peoples (Cambridge: Polity Press).

Evans, B. and Giroux, H. A. (2015), Disposable Futures: The Seduction of Violence in the Age of the Spectacle (San Francisco: City Lights Books).

Evans, B. (2008), 'The Zapatista Insurgency: Bringing the Political Back into Conflict Analysis', New Political Science, 30:4, 497-520.

Evans, B. (2010), 'Life Resistance: Towards a Different Concept of the Political', Deleuze Studies, 4:3, 142-62.

Evans, B. (2013), Liberal Terror (Cambridge: Polity Press).

Evans, B. (2021), Ecce Humanitas: Beholding the Pain of Humanity (New York: Columbia University Press, forthcoming 2021).

Forti, S. (2014), New Demons: Rethinking Power and Evil Today (Stanford: Stanford University Press).

Foucault, M. (2003), Society Must Be Defended: Lectures at the College de France 1975-1976 (New York: Picador).

Freud, S. (1991), Beyond the Pleasure Principle (New York: Dover Publications).

Girard, R. (2005), Violence and the Sacred (London: Continuum).

Gray, J. (2007), Black Mass: Apocalyptic Religion and the Death of Utopia (London: Penguin).

Grossman, D. (2009), On Killing: The Psychological Cost of Learning to Kill in War and Society (New York: Back Bay Books).

Pinker, S. (2011), The Better Angels of Our Nature: Why Violence Has Declined (London: Viking).

Said, E. (2019), Orientalism (London: Penguin Classics).

Virilio, P. and Lotringer, S. (1983), Pure War (New York: Semiotext(e)).

Zimbardo, P. (2008), The Lucifer Effect: How Good People Turn Evil (London: Rider). 